\title{
Guanfacine and Clonidine Reduce Defoliation and Phytotoxicity Associated with Abscission Agents
}

\author{
Jacqueline K. Burns, ${ }^{1}$ Luis V. Pozo, ${ }^{2}$ Rongcai Yuan, ${ }^{2}$ and Brandon Hockema ${ }^{3}$ \\ Citrus Research and Education Center, University of Florida, 700 Experiment Station Road, Lake Alfred, \\ FL 33850
}

\begin{abstract}
AdDitional INDEX wORDS. $\alpha_{2}$-adrenergic agonist, auxin, citrus, 5-chloro-3-methyl-4-nitro-pyrazole, ethephon, ethylene, Gbinding protein, 1-methylcyclopropene, metsulfuron-methyl, peach

Aвstract. Guanfacine and clonidine were combined with ethephon or metsulfuron-methyl in the spray tank and applied as foliar sprays to Citrus sinensis L. Osb. 'Valencia', Citrus madurensis Loureiro (calamondin), and Prunus persica 'Elberta' to determine their effects on leaf loss, fruit detachment force (FDF), immature fruit loss, and twig dieback. In 'Valencia' orange, 'Elberta' peach and calamondin, guanfacine and clonidine effectively reduced ethephon-induced defoliation in all three tree species, whereas only guanfacine was effective with metsulfuron-methyl applications in 'Valencia'. The ability of ethephon to reduce FDF in 'Valencia' was only minimally impaired by guanfacine but not impaired by clonidine. Both guanfacine and clonidine diminished the capacity of metsulfuron-methyl to reduce FDF. Guanfacine reduced immature fruit loss of 'Valencia' caused by metsulfuron-methyl and reduced twig-dieback. Leaf loss was reduced whether guanfacine or clonidine were applied with ethephon, or 24 hours or 17 days before ethephon application. Guanfacine and clonidine reduced leaf loss induced by continuous exposure of potted calamondin trees to ethylene, and leaf loss was similar with guanfacine and 1-methylcyclopropene (1-MCP) treatments. In separate experiments, guanfacine and clonidine were unable to block ethylene perception in Arabidopsis seedlings and petunia flowers but promoted rooting in coleus and tomato vegetative cuttings, suggesting that these compounds have auxin-like activity. The results demonstrate the potential to enhance selectivity of abscission agents with guanfacine and clonidine. Chemical names used: 2-[(2,6-dichlorophenyl)amino]-2-imidazoline, clonidine; 5-chloro-3-methyl-4-nitro-pyrazole, CMN-P; [(2,6-dichlorophenyl)acetyl]guanidine, guanfacine; [(2-chloroethyl)phosphonic acid, ethephon; indole-3-butyric acid, IBA; 1-methylcyclopropene, 1-MCP.
\end{abstract}

The use of mechanical technologies for harvesting Florida processing oranges is steadily increasing. In general, mechanical harvesting efficiencies are good, especially in early season varieties such as 'Hamlin'. However, mechanical harvesting of late season 'Valencia' can be less satisfactory as harvesting becomes less selective and subsequent yield is reduced because young developing fruit are also harvested. Mechanical harvesting efficiencies would improve if a suitable abscission agent could be identified. An objective of our research program is to identify abscission agent candidates or compounds that may influence the abscission process in citrus. A suitable abscission agent for Florida citrus must be selective for mature fruit, nonphytotoxic, loosen fruit soon after application and be economical to apply. Most abscission agents cause excessive defoliation in citrus. Twig dieback and abscission of young developing fruit are also observed, particularly with application rates necessary to sufficiently loosen mature fruit (Kender et al., 1999; Pozo and Burns, 2001). Although calcium reduced ethephon-induced defoliation in pecan (Martin et al., 1980), calcium hydroxide or calcium acetate treatments did not reduce defoliation to acceptable levels in oranges grown under Florida conditions (Kender et al., 2000).

Currently there are no registered abscission agents for citrus. One compound, 5-chloro-3- methyl-4-nitro-pyrazole (CMN-P), was extensively tested in earlier Florida abscission programs (Wilson et al., 1977). This compound was selective for mature fruit, caused no canopy injury and loosened fruit within 3 to $5 \mathrm{~d}$. Despite its favorable performance, CMN-P was never registered

Received for publication 18 Mar. 2002. Accepted for publication 2 Oct. 2002. This research was supported by the Florida Agricultural Experiment Station and a grant from the Florida Dept. of Citrus. Approved for publication as journal series R-08717.

'Professor.

${ }^{2}$ Postdoctoral associate.

${ }^{3}$ Senior biological scientist. largely because of economic concerns and unknown toxicological properties. One compound, metsulfuron-methyl, markedly reduced fruit detachment force (FDF), but significant leaf loss and phytotoxicity were observed (Burns et al., 1999; Hartmond et al., 2000a; Kender et al., 1999). Ethephon, an abscission agent used with plums, cherries and olives (Bukovac et al., 1969; Martin et al., 1981), caused gummosis and excessive defoliation at rates necessary to achieve acceptable fruit loosening in citrus (Kender et al., 2000; Pozo and Burns, 2001). If these abscission agents are to be adapted for use in citrus, treatments that reduce post-application side-effects are needed.

We have screened several hundred compounds that were selected on the basis of metabolism affected during abscission or chemical structural similarity with compounds known to affect abscission (Burns, 2002). One group of compounds targeted in our screening program is the auxins or auxin-like materials. Auxins are known to reduce sensitivity of tissues to ethylene, and cross-talk between these hormones and others can significantly influence the abscission process (Brown, 1997; Yuan et al., 2001). Preliminary work demonstrated that application of treatment combinations of auxins such as naphthalene acetic acid, 2,4dichlorophenoxyacetic acid and indole-3-butyric acid (IBA) with abscission agents reduced defoliation but also eliminated the<smiles>Clc1cccc(Cl)c1N=C1NCCN1</smiles><smiles>N=C(N)NC(=O)Cc1c(Cl)cccc1Cl</smiles>
clonidine guanfacine

Fig. 1. Chemical structures of clonidine and guanfacine. 
reduction in FDF. Even at low auxin dosages, selective mature fruit abscission was not achieved.

Other compounds were sought with altered structures that could have weak auxin activity. Guanfacine and clonidine (Fig. 1) were selected for screening based on structural similarity with auxins of the benzoic acid and phenoxyacetic acid series, but notable differences exist. For example, both compounds are basic and contain a guanidine moiety. However, neither compound contains a carboxylic acid or ether group indicative of the phenoxyacetic acid series of auxins. Guanfacine and clonidine are pharmacological compounds known as $\alpha_{2}$-adrenergic agonists important in regulating neurotransmitter release in animals. In this report, we describe the reduction of post-application sideeffects of abscission agents with the use of guanfacine and clonidine.

\section{Materials and Methods}

Compounds. Guanfacine ([(2,6-dichlorophenyl)acetyl $]$ guanidine) was purchased from Tocris Cookson, Inc. (Ellisville, Mo.). Clonidine (2-[(2,6-dichlorophenyl)amino]-2-imidazoline) and indole-3-butyric acid were purchased from Sigma-Aldrich Chemical Co. (St. Louis, Mo.). 1-Methylcyclopropene (1-MCP, EthylBloc) was purchased from Floralife, Inc. (Walterboro, S.C.). Ethephon (Aventis, Ethrel, [2-chloroethyl] phosphonic acid), Ally [Dupont Chemical, metsulfuron-methyl, methyl 2-([([(4methoxy-6-methyl-1,3,5-triazin-2yl) amino] carbonyl) amino] sulfonyl) benzoate] and Kinetic (Setre Chemical Co.) were purchased from Helena Chemical Company (Collierville, Tenn.). CMN-P (17.18\% active ingredient) was applied as formulated by Abbott Laboratories $\approx 30$ years ago (Wilson, 1973). The compound is remarkably stable as formulated, and we routinely isolate CMN-P from the original formulation by distillation followed by partition against ethyl acetate and hexane. The identity of the isolated compound was confirmed by NMR and GC-MS. The efficacy of formulated CMN-P and reisolated CMN-P was identical.

Plant material. Citrus sinensis (L.) Osb. 'Valencia' grown at the Citrus Research and Education Center, Lake Alfred, Fla., was used. 'Valencia' trees were 12 to 15 years of age and were grown on 'Swingle' rootstock. Greenhouse and ethylene chamber studies were conducted with potted (12-L pot size) 3-year-old Citrus madurensis Loureiro (calamondin) or 1-year-old peach (Prunus persica 'Elberta') trees purchased from a local nursery. Rooting experiments were conducted with coleus (Solenostemon scutellarioides) and tomato (Lycopersicon esculentum) plants purchased from a local nursery. Wild type Arabidopsis thaliana 'Columbia' seeds were purchased from Lehle Seeds (Round Rock, Texas) and the ethylene perception mutant etrl seed was obtained from the Arabidopsis Biological Resource Center (Columbus, Ohio). Petunia seed (Petunia $\times$ hybrida 'Mitchell Diploid') was a generous gift from David Clark, University of Florida. Seed were germinated and plants grown in a greenhouse. Flowers were harvested $\approx 45 \mathrm{~d}$ after germination.

Treatment of Plant material. Compounds were applied to 'Valencia' tree sectors or individual branches during the 1999, 2000, and 2001 seasons. Typically, treatments were applied from mid March through mid June, and average temperatures ranged from 20 to $23{ }^{\circ} \mathrm{C}$ during the trials. For sector sprays, at least three trees were used per treatment, and each tree was partitioned into three sectors. Treatments were randomly assigned to a tree sector. Each tree sector contained at least 100 fruit. Within each sector, one main scaffold branch was identified and leaves were counted. Each branch contained at least 250 leaves. Branch sprays consisted of five branches on each of three trees, with at least 10 fruit/ branch. Leaves were counted on each branch and consisted of at least 35 leaves. Both tree sector and branch tests were replicated three times. Ethephon or metsulfuron-methyl was applied alone or in combination with guanfacine $\left(2 \mathrm{~mm}, 564 \mathrm{mg} \cdot \mathrm{L}^{-1}\right)$ or clonidine $\left(2 \mathrm{~mm}, 532 \mathrm{mg} \cdot \mathrm{L}^{-1}\right)$. The tank mixture was prepared by dissolving guanfacine or clonidine in an aqueous solution containing $0.125 \%$ Kinetic, an organosilicone adjuvant. Ethephon was added to the tank mixture to give a final concentration of $200 \mathrm{mg} \cdot \mathrm{L}^{-1}$. Metsulfuron-methyl was added to achieve a final concentration of $2 \mathrm{mg} \cdot \mathrm{L}^{-1}$. The $\mathrm{pH}$ of each solution remained below 5.5. Treatments were applied less than $1 \mathrm{~h}$ after compounds were combined in the spray tank. For peach, treatments containing ethephon with and without $1 \mathrm{~mm}$ guanfacine or $1 \mathrm{~mm}$ clonidine were applied to canopies of trees in 4-L pots. Three trees were used per treatment, and the experiment repeated twice. Each tree contained at least 30 leaves. Trees were kept in a greenhouse, where average temperature during the trials was $28^{\circ} \mathrm{C}$. Treatments were applied to citrus and peach canopies until solutions began to runoff the leaves.

Whole calamondin trees in $12-\mathrm{L}$ pots were used to determine the effect of preapplication treatments of guanfacine and clonidine on reduction of ethephon-induced leaf loss. Each tree contained at least 100 leaves. Aqueous solutions of $1 \mathrm{~mm}$ guanfacine or $1 \mathrm{~mm}$ clonidine containing $0.125 \%$ Kinetic were applied to calamondin trees in a greehouse $24 \mathrm{~h}$ or $17 \mathrm{~d}$ before application of $400 \mathrm{mg} \cdot \mathrm{L}^{-1}$ ethephon. Solutions were applied to the canopy until runoff. Six trees were used for each treatment, and the test was repeated twice. Average temperature during the trials was $29^{\circ} \mathrm{C}$.

Ethylene treatments on whole calamondin trees in 12 -L pots described above were performed in a $6.2 \times 4.6 \times 3 \mathrm{~m}$ citrus degreening room located at the Citrus Research and Education Center. Tree canopies were sprayed with water, $2 \mathrm{~mm}$ guanfacine or $2 \mathrm{~mm}$ clonidine. A subset of trees were treated with $600 \mathrm{~nL} \cdot \mathrm{L}^{-1} 1$ MCP in a separate $82 \mathrm{~m}^{3}$ airtight storage room $16 \mathrm{~h}$ before application of water, guanfacine, or clonidine. Application protocol to achieve this concentration of 1 -MCP was performed according to the manufacturer's recommendation. After application of agonists, plants were immediately transferred to the degreening room and treated with continuous ethylene $\left(1 \mu \mathrm{L} \cdot \mathrm{L}^{-1}\right.$ final concentration, $\approx 25^{\circ} \mathrm{C}$ and $85 \% \mathrm{RH}$ ) for $160 \mathrm{~h}$ under light conditions of $\approx 100 \mu \mathrm{mol} \cdot \mathrm{m}^{-2} \cdot \mathrm{s}^{-1}$ for a $12-\mathrm{h}$ cycle each day. Six trees were used for each treatment, and the test was repeated twice.

All Arabidopsis tests were done in the dark. Wild type and etr 1 Arabidopsis seeds were placed onto germination paper in petri plates and imbibed in water, or $1 \mathrm{~mm}$ guanfacine or $1 \mathrm{~mm}$ clonidine for $2 \mathrm{~d}$ at $4^{\circ} \mathrm{C}$. Four treatment plates were used, and each plate contained $\approx 50$ seeds. Plates were then transferred to $21^{\circ} \mathrm{C}$ for ethylene treatment. Petunia flowers with $3 \mathrm{~cm}$ pedicel were placed into $2 \mathrm{~mL}$ Eppendorf microfuge tubes containing water, 2 mu guanfacine or $2 \mathrm{~mm}$ clonidine. Each treatment contained six flowers. Ethylene $\left(10 \mu \mathrm{L} \cdot \mathrm{L}^{-1}\right.$ final concentration $)$ was injected through a septum into either sealed petri plates containing Arabidopsis seeds or a plexiglass chamber $(0.6 \times 0.5 \times 0.5 \mathrm{~m})$ containing petunia flower explants. Arabidopsis and petunia flower tests were repeated at least five times.

For rooting studies, $15-\mathrm{cm}$ stem cuttings with the apical meristem intact were removed from coleus and tomato plants. Leaves were removed from the lower $5 \mathrm{~cm}$ and cuttings were submerged into solutions containing either $800 \mathrm{mg} \cdot \mathrm{L}^{-1} \mathrm{IBA}, 800$ 

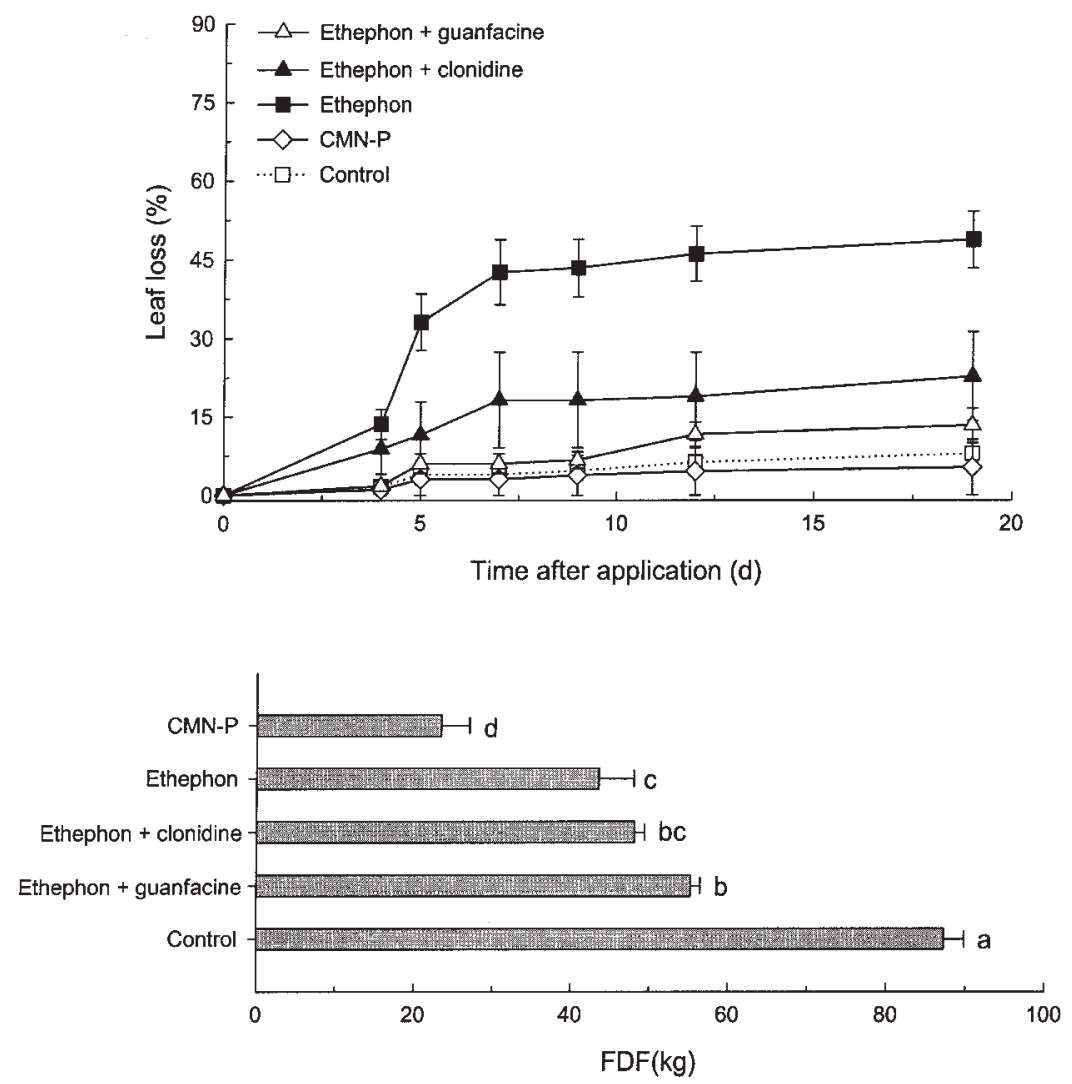

Fig. 2. (top) Leaf loss (\%) and FDF (bottom) in 'Valencia' orange treated with $200 \mu \mathrm{L} \cdot \mathrm{L}^{-1}$ ethephon with and without $2 \mathrm{~mm}$ guanfacine or $2 \mathrm{~mm}$ clonidine. Water and $200 \mathrm{mg} \cdot \mathrm{L}^{-1} \mathrm{CMN}-\mathrm{P}$ were included for comparison. Bars represent SE mean. For FDF, means followed by the same letter were not significantly different by Duncan's multiple range test at $P \leq 0.05$.

$\mathrm{mg} \cdot \mathrm{L}^{-1}$ guanfacine, $800 \mathrm{mg} \cdot \mathrm{L}^{-1}$ clonidine or water alone. After 10 min, cuttings were removed from treatment solutions and placed in a mist bed containing 1 part Perlite : 2 parts Metro Mix 500 (Scotts, Marysville, Ohio) under ambient light. At least six cuttings were used for each treatment, and rooting trials were replicated at least four times. Average temperature during the rooting trials was $29^{\circ} \mathrm{C}$.

Measurements. Defoliation was measured and expressed as percentage of leaf loss by counting the total number of leaves at the beginning of each test and dividing by the number of leaves dropped at various times after application. Fruit detachment force in $\mathrm{kg}$ was measured within $5 \mathrm{~d}$ (ethephon tests) or $10 \mathrm{~d}$ (metsulfuronmethyl tests) after application using a Force Five pull-force gauge (Wagner Instruments, Greenwich, Conn.) as described (Hartmond et al., 2000a). Briefly, fruit were clipped with approximately $3 \mathrm{~cm}$ stem, inserted into the gauge, and the stem pulled parallel to the fruit axis until it separated at the abscission zone. The effect of ethylene on the triple response (inhibition and swelling of the hypocotyl, inhibition of root elongation and exaggeration of apical hook curvature) of Arabidopsis seedlings (Bleecker and Kende, 2000) was noted visually. The etr 1 mutant is defective in ethylene perception, and consequently these plants are insensitive to ethylene and do not exhibit the triple response. The effect of guanfacine or clonidine on blocking ethylene perception in ethylene-treated wild type seedlings was rated visually by evaluating the existence of the triple response and comparing with ethylene-treated etr 1 . Arabidopsis germination and seedling evaluation experiments typically ran for $5 \mathrm{~d}$. Wilting of petunia flower petals was also evaluated visually. Petunia wilting experiments typically ran for $3 \mathrm{~d}$. For rooting experiments, root number, root length, and root fresh weight were taken 10 or $11 \mathrm{~d}$ after application.

Percentage data were transformed to stabilize the variance using MS-Excel arcsin transformation functions. Analysis of variance and Duncan's multiple range test was preformed on all data using the SAS statistical package (SAS Inst. Inc., Cary N.C.).

\section{Results and Discussion}

Combining either guanfacine or clonidine with ethephon in the spray tank reduced leaf loss associated with ethephon application in 'Valencia' orange (Fig. 2). Leaf loss in ethephon-treated trees was significantly greater than any other treatment $4 \mathrm{~d}$ after application $(P \leq 0.05)$. Although guanfacine was equally effective as clonidine at equivalent concentrations, mean leaf loss was less with guanfacine. Leaf loss was minimal in treatments with the adjuvant only and CMN-P. The FDF was similar for clonidine plus ethephon and ethephon alone. Guanfacine plus ethephon slightly diminished the ability of ethephon to reduce FDF. The FDF was lowest with CMN-P. Guanfacine and clonidine became less effective as ethephon concentrations increased (data not shown). In peach trees, significant differences in leaf loss were measured between ethephon treatment and either guanfacine or clonidine + ethephon $15 \mathrm{~d}$ after application $(P$ $\leq 0.05)$. Clonidine was more effective than guanfacine at equivalent concentrations (Fig. 3). Guanfacine or clonidine alone had no apparent effect on leaf drop or FDF in 'Valencia' or peach (data not shown). It is well known that acidic solutions above $\mathrm{pH} 5.5$ promote chemical breakdown of ethephon (Cooke and Randall, 1968; Warner and Leopold, 1969). Since the pH of spray solutions containing both ethephon and guanfacine or clonidine was 5.5 or less, it was unlikely that chemical breakdown of ethephon before canopy application could account for the ability of guanfacine and clonidine to control leaf loss. Nevertheless, we measured ethylene evolution from solutions of guanfacine or clonidine plus ethephon combinations held for periods up to $2 \mathrm{~h}$

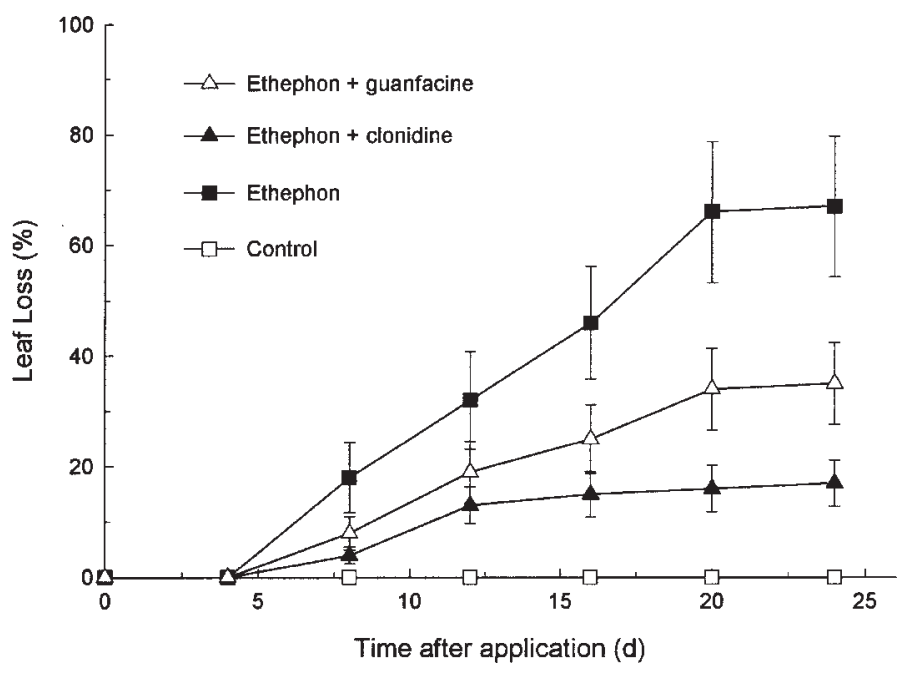

Fig. 3. Leaf loss $(\%)$ in peach treated with $200 \mathrm{mg} \cdot \mathrm{L}^{-1}$ ethephon with and without $1 \mathrm{~mm}$ guanfacine or $1 \mathrm{~mm}$ clonidine. Bars represent SE mean. 
Table 1 . The effect of $24 \mathrm{~h}$ ( $24 \mathrm{~h}$ prior) or $17 \mathrm{~d}$ (17 $\mathrm{d}$ prior) preapplications of $1 \mathrm{~mm}$ guanfacine or $1 \mathrm{~mm}$ clonidine on ethephon-induced defoliation in potted calamondin trees. Ethephon was applied on separate trees at the time ethephon was applied to trees previously sprayed with guanfacine or clonidine. Leaf loss (\%) was measured $10 \mathrm{~d}$ or 11 $\mathrm{d}$ after ethephon application for the $24 \mathrm{~h}$ and $17 \mathrm{~d}$ preapplication, respectively. Ethephon was applied at $400 \mathrm{mg} \cdot \mathrm{L}^{-1}$.

\begin{tabular}{lcr}
\hline & \multicolumn{2}{c}{$\begin{array}{c}\text { Guanfacine or clonidine } \\
\text { application time }\end{array}$} \\
\cline { 2 - 3 } Treatment & $24 \mathrm{~h}$ prior & $17 \mathrm{~d}$ prior \\
\hline Control & $7.2 \mathrm{~b}^{\mathrm{z}}$ & $4.8 \mathrm{~b}$ \\
Ethephon & $25.6 \mathrm{a}$ & $24.1 \mathrm{a}$ \\
Guanfacine followed by ethephon & $2.5 \mathrm{~b}$ & $2.5 \mathrm{~b}$ \\
Clonidine followed by ethephon & $5.9 \mathrm{~b}$ & $2.5 \mathrm{~b}$ \\
\hline
\end{tabular}

${ }^{\mathrm{z}}$ Means followed by the same letter within a column are not significantly different, $P \leq 0.05$.

using gas chromatography. No ethylene evolution from these solutions was detected (data not shown).

Calamondin trees in pots were used to determine if guanfacine or clonidine preapplications were effective in preventing leaf loss associated with ethephon applications. As noted previously (Burns, 2002), calamondin trees are less sensitive than 'Valencia' to ethephon, as application of $400 \mathrm{mg} \cdot \mathrm{L}^{-1}$ caused between $24 \%$ to $26 \%$ leaf loss (Table 1). Application of guanfacine or clonidine 24 $\mathrm{h}$ or $17 \mathrm{~d}$ before ethephon application was sufficient to reduce leaf loss to control levels. This suggests that the action of guanfacine and clonidine is long-lived in the plant and not related to interaction of these compounds with ethephon at the time of application. Why the action was long-lived is not known. Once absorbed, the compounds themselves could have long halflives in plants or elicit a set of responses that are long-lived.

Metsulfuron-methyl is a sulfonylurea herbicide that inhibits acetolactate synthase, an enzyme involved in the biosynthesis of branched chain amino acids (LaRossa and Schloss, 1984). The sulfonylurea and imidazolinone herbicides were reported to induce citrus mature fruit abscission (Wilcox and Taylor, 1997). Although these compounds were later shown to cause ethylene production and fruit drop in various citrus fruit (Burns et al., 1999), defoliation and twig dieback were significant side-effects (Kender et al., 1999). In our current work, combination treatments of metsulfuronmethyl with guanfacine or clonidine were applied to 'Valencia' orange 3 weeks after bloom. This afforded an opportunity to not only determine the effect on defoliation and FDF, but also to determine the effect on young developing fruitlet loss and twig dieback. Combination of guanfacine with metsulfuron-methyl significantly reduced leaf loss beginning $10 \mathrm{~d}$ after application $(P$ $\leq 0.05$ ), whereas clonidine plus metsulfuronmethyl did not differ from metsulfuronmethyl alone at any time (Fig. 4). Reduction in FDF was not as great with guanfacine plus metsulfuron-methyl treatments, although they were near the estimated threshold for complete fruit removal by trunk-shaking mechanical harvesters (Wilson, 1973). Immature fruit loss was significantly less in the guanfacine plus metsulfuron-methyl treatment compared with metsulfuron-methyl treatment alone ( $P$ $\leq 0.05$ ); however, yield reductions would still be expected. Compared with metsulfuron-methyl alone, twig dieback was greatly reduced in guanfacine plus metsulfuron-methyl applications but not with clonidine plus metsulfuron-methyl applications (data not shown).

The ability of these two $\alpha_{2}$-adrenergic agonists, particularly guanfacine, to reduce phytotoxicity associated with ethephon and metsulfuron-methyl applications suggests that their action may be related to ethylene perception, signal transduction or downstream ethylene responses. The involvement of ethylene in the abscission process is well-known (Brown, 1997). Ethylene is thought to initiate abscission by first binding to receptors which then lead to events culminating in organ abscission. To determine if the action of guanfacine and clonidine was related to ethylene perception, comparisons were made between these compounds and 1-MCP, a compound that binds to the ethylene receptor and inhibits ethylene perception (Sisler and Serek, 1996). Continuous exposure of potted calamondin trees to $1 \mu \mathrm{L} \cdot \mathrm{L}^{-1}$ ethylene caused

Fig. 4. (top) Leaf loss (\%), (middle) immature fruit loss (\%) and (bottom) reduction in FDF in 'Valencia' orange treated with $2 \mathrm{mg} \cdot \mathrm{L}^{-1}$ metsulfuronmethyl with and without $2 \mathrm{~mm}$ guanfacine or $2 \mathrm{~mm}$ clonidine. Water and 200 $\mathrm{mg} \cdot \mathrm{L}^{-1} \mathrm{CMN}-\mathrm{P}$ were included as controls. Bars represent SE mean. For FDF, means followed by the same letter were not significantly different at $P \leq 0.05$.
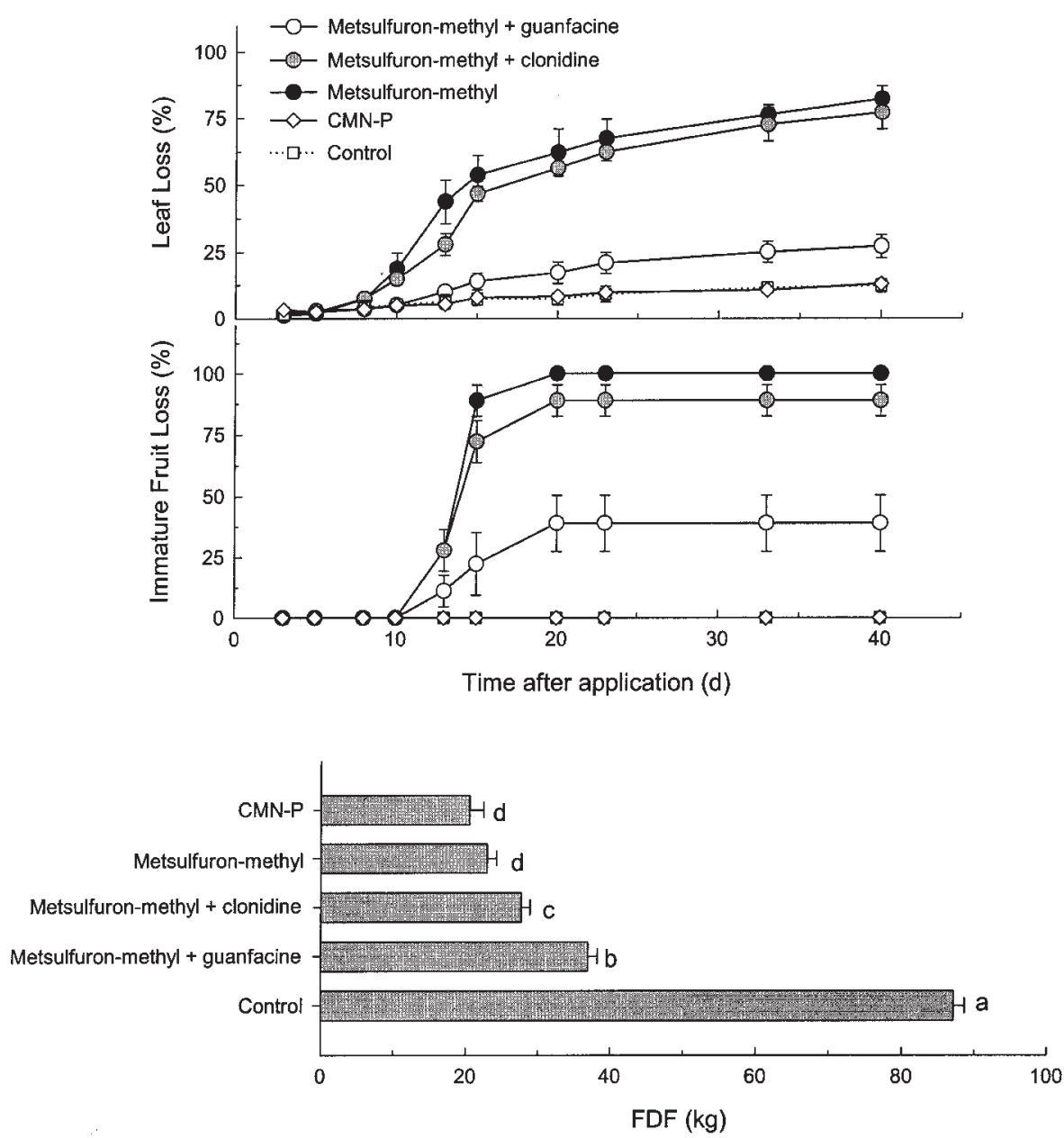
Table 2. Cumulative leaf loss $(\%)$ in potted calamondin trees under continuous $1 \mu \mathrm{L} \cdot \mathrm{L}^{-1}$ ethylene exposure. Tree canopies were sprayed with water (control), $2 \mathrm{mM}$ guanfacine or $2 \mathrm{mM}$ clonidine before ethylene treatment. Canopies receiving 1-MCP were treated for $16 \mathrm{~h}$ before application of water, guanfacine, or clonidine.

\begin{tabular}{|c|c|c|c|c|c|c|}
\hline \multirow[b]{2}{*}{ Treatment } & \multicolumn{6}{|c|}{ Cumulative leaf loss (\%) } \\
\hline & $24 \mathrm{~h}$ & $48 \mathrm{~h}$ & $72 \mathrm{~h}$ & $96 \mathrm{~h}$ & $120 \mathrm{~h}$ & $160 \mathrm{~h}$ \\
\hline Control & $1.1 \mathrm{a}^{\mathrm{z}}$ & $34.2 \mathrm{a}$ & $53.3 \mathrm{a}$ & $63.7 \mathrm{a}$ & $70.2 \mathrm{a}$ & $81.5 \mathrm{a}$ \\
\hline Clonidine & $2.3 \mathrm{a}$ & $15.5 \mathrm{~b}$ & $24.6 \mathrm{~b}$ & $31.6 \mathrm{~b}$ & $39.8 \mathrm{~b}$ & $58.1 \mathrm{~b}$ \\
\hline Guanfacine & $2.1 \mathrm{a}$ & $6.6 \mathrm{c}$ & $15.9 \mathrm{c}$ & $23.0 \mathrm{c}$ & $29.2 \mathrm{c}$ & $43.9 \mathrm{c}$ \\
\hline 1-MCP & $1.6 \mathrm{a}$ & $6.1 \mathrm{c}$ & $15.0 \mathrm{c}$ & $17.0 \mathrm{~cd}$ & $25.7 \mathrm{~cd}$ & $38.4 \mathrm{~cd}$ \\
\hline 1-MCP + clonidine & $1.4 \mathrm{a}$ & $4.5 \mathrm{c}$ & $10.7 \mathrm{de}$ & $13.1 \mathrm{de}$ & $19.8 \mathrm{de}$ & $33.3 \mathrm{~d}$ \\
\hline 1-MCP + guanfacine & $1.9 \mathrm{a}$ & $4.8 \mathrm{c}$ & $7.8 \mathrm{e}$ & $8.8 \mathrm{e}$ & $12.2 \mathrm{e}$ & $21.5 \mathrm{e}$ \\
\hline
\end{tabular}

${ }^{\mathrm{z}}$ Mean separation within column by Duncan's multiple range test, $P \leq 0.05$.

$>80 \%$ leaf loss after $160 \mathrm{~h}$ (Table 2). Leaf loss was delayed by 1$\mathrm{MCP}$, and it greatly reduced the total amount of leaf loss after 160 $\mathrm{h}$ ethylene treatment. Leaf loss with guanfacine alone was for practical purposes no different than 1-MCP. Clonidine delayed the onset and reduced leaf loss, but was significantly higher after $24 \mathrm{~h}$ than with guanfacine. When compared with 1-MCP alone, combining guanfacine or clonidine with 1-MCP further reduced leaf loss associated with ethylene treatment, especially with longer durations. This suggests that guanfacine and clonidine may act as ethylene perception inhibitors or interact with the signal transduction process in some way. However, since our previous observations showed that auxins also reduced defoliation associated with ethylene (ethephon) applications in citrus, auxin-like effects associated with guanfacine or clonidine action could not be discounted.

To explore the ethylene perception inhibitor and auxin-like effects associated with guanfacine and clonidine, the ability of these compounds to eliminate the triple response in germinating Arabidopsis seedlings, wilting in petunia flower petals, and to promote rooting in vegetative cuttings of coleus and tomato was determined. In the presence of ethylene, the triple response was observed in wild-type Arabidopsis seedlings germinated in guanfacine or clonidine but not in etrl seedlings (Fig. 5). In addition, petals of petunia flowers held in an ethylene atmosphere wilted in the presence of these compounds, but not 1-MCP. This demonstrated that guanfacine and clonidine did not block the perception of ethylene. Rooting was promoted in vegetative cuttings of coleus and tomato with guanfacine and clonidine (Fig. 5). Root number, total root length and root fresh weight of guanfacine- or clonidine-treated cuttings was greater than the control, but generally not as great as those treated with IBA at equivalent concentrations. The promotive effect of guanfacine and clonidine on rooting suggests that these compounds have auxin-like activity.

We do not know the precise mode of action of guanfacine and clonidine. These compounds are known as $\alpha_{2}$-adrenergic agonists. Compounds in this class activate $\alpha_{2}$-adrenergic receptors located on both post- and presynaptic termini of neurons in animals and have an important role in regulating neurotransmitter release. The receptors mediate their functions through signaling pathways that involve interactions with heterotrimeric G-binding proteins. These proteins are GTPases composed of $\alpha, \beta$, and $\gamma$ subunits associated with plasma membrane-localized receptors (Feldman et al., 1997). Upon binding of a ligand to the membranebound receptor, heterotrimeric G-protein subunit(s) are activated and interact with downstream effectors, such as adenylate cyclase and cellular $\mathrm{Ca}^{2+}$ transport mechanisms, ultimately leading to a response. Although plants were thought to contain only the $\alpha$

\begin{tabular}{|llcc|} 
& \multicolumn{2}{l}{ Arabidopsis } & $\underline{\text { Petunia }}$ \\
& $\underline{\text { wt }}$ & $\underline{\text { etrl }}$ & \\
Water & + & - & + \\
Guanfacine & + & - & + \\
Clonidine & + & - & + \\
1-MCP & na & na & - \\
\hline
\end{tabular}

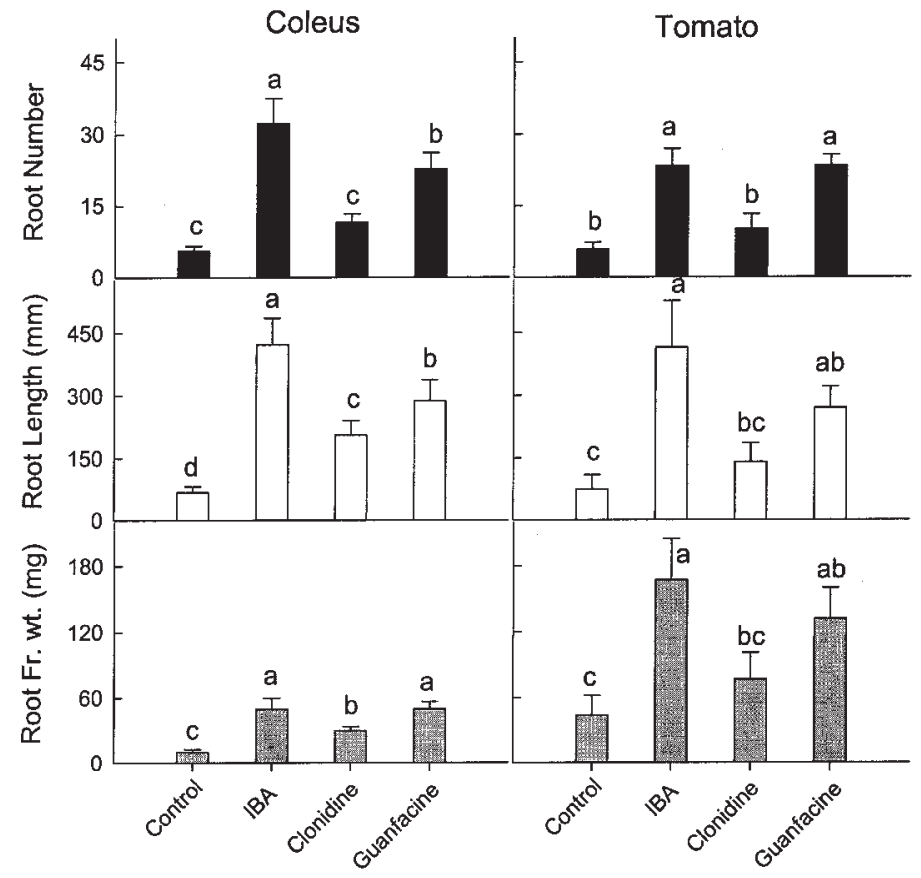

Treatments

Fig. 5. Assessment of guanfacine and clonidine as ethylene perception inhibitors (top panel) and auxins (bottom panel). (top) Wild type and etrl Arabidopsis seed were germinated in a $10 \mu \mathrm{L} \cdot \mathrm{L}^{-1}$ ethylene atmosphere in water, $2 \mathrm{~mm}$ guanfacine or $2 \mathrm{~mm}$ clonidine in the dark. After $4 \mathrm{~d}$ at $21^{\circ} \mathrm{C}$, the presence $(+)$ or absence $(-)$ of the seedling triple response was noted. na $=$ not applied. Petunia flowers were harvested and treated with $1-\mathrm{MCP} 16 \mathrm{~h}$ before $10 \mu \mathrm{L} \cdot \mathrm{L}^{-1}$ ethylene treatment. Additional flowers were harvested and placed in solutions containing water, $2 \mathrm{~mm}$ guanfacine, or $2 \mathrm{~mm}$ clonidine. After $4 \mathrm{~d}$ at $21^{\circ} \mathrm{C}$, the presence $(+)$ or absence $(-)$ of petal wilting was noted. na, not applied. (bottom) Coleus or tomato vegetative cuttings were treated with $800 \mathrm{mg} \cdot \mathrm{L}^{-1} \mathrm{IBA}$, clonidine, or guanfacine as described in the text. Root number, total root length, and root fresh weight were measured. Bars indicate SE mean. Means followed by the same letter within the series were not significantly different at $P \leq 0.05$. 
subunit of heterotrimeric G-proteins, recent work has demonstrated the presence of both $\beta$ and $\gamma$ subunits (Assmann, 2002; Fujisawa et al., 2001). Candidates for membrane-associated receptors in plants have been isolated but their functions have not been established.

Signaling initiated by guanfacine or clonidine could begin by directly binding to a putative receptor that prevents abscission and senescence, possibly by repressing downstream signaling events induced by ethylene, or alternatively, they may interact with G-proteins themselves to elicit a biological response. Recent work has demonstrated the diverse roles of G-binding proteins in plant signaling pathways that impact processes related to hormone perception and action (Assmann, 2002; Li et al., 2001). Gbinding proteins are generally thought to be positive regulators of plant growth and have been shown to influence $\mathrm{Ca}^{2+}$ gradients involved in pollen tube growth and actin assembly, promote lateral root number and growth, and alter sensitivity to GA and brassinosteroid (Gelli et al., 1997; Li et al., 2001; Ma et al., 1999; Ullah et al., 2002). We have demonstrated that both guanfacine and clonidine promoted lateral root number and growth, reduced ethylene-induced defoliation and minimized phytotoxicity associated with metsulfuron-methyl application. The mode of action of guanfacine and clonidine may be related to their ability to impact G-binding protein-related signaling pathways following perception of phytohormones or other elicitors. These pathways may be developmentally and differentially regulated, since guanfacine and clonidine had a greater effect on leaf abscission than fruit loosening.

In conclusion, guanfacine and clonidine were shown to reduce defoliation and phytotoxicity associated with abscission agent application and did not greatly impair the ability of the abscission agent to loosen fruit. The high cost of $\alpha_{2}$-adrenergic agonists and their use as pharmacological agents may eliminate these compounds from serious consideration for agricultural use. However, these compounds have the potential to increase selectivity of abscission agents by lowering leaf loss associated with abscission agents. Our research program will continue to focus on selection and adaptation of abscission-related compounds suitable for the citrus industry.

\section{Literature Cited}

Assmann, S.M. 2002. Heterotrimeric and unconventional GTP-binding proteins in plant cell signaling. Plant Cell 14:S355-S373.

Bleecker, A.B and H. Kende. 2000. Ethylene: A gaseous signal molecule in plants. Annu. Rev. Cell Biol. 16:1-18.

Brown, K.M. 1997. Ethylene and abscission. Physiol. Plant. 100:567576.

Bukovac, M.J., F. Zucconi, R.P. Larsen, and C.D. Kesner. 1969. Chemical promotion of fruit abscission in cherries and plums with special reference to 2-chloroethylphosphonic acid. J. Amer. Soc. Hort. Sci. 94:226-230.

Burns, J.K. 2002. Using molecular biology tools to search for citrus abscission agents. HortScience 37:459-464.

Burns, J.K., U. Hartmond, and W.J. Kender. 1999. Acetolactate synthase inhibitors increase ethylene production and cause fruit drop in citrus. HortScience 34:908-910.

Cooke, A.R. and D.I. Randall. 1968. 2-Haloethanephosphonic acids as ethylene releasing agents for induction of flowering in pineapples. Nature 218:974-975.

Feldman, R.S., J.S. Meyer, and L.F. Quenzer. 1997. Catecholamines, p. 277-344. In: Principles of neuropsychopharmacology. Sinauer Assoc., Inc., Sunderland, Mass.

Fujisawa, Y., H. Kato, and Y. Iwasaki. 2001. Structure and function of heterotrimeric G- proteins in plants. Plant Cell Physiol. 42:789-794.

Gelli, A., V.J. Higgins, and E. Blumwald. 1997. Activation of plant plasma membrane $\mathrm{Ca}^{2+}$-permeable channels by race-specific fungal elicitors. Plant Physiol. 113:269-279.

Hartmond, U., J.D. Whitney, J.K. Burns, and W.J. Kender. 2000a. Seasonal variation in the response of 'Valencia' orange to two abscission compounds. HortScience 35:226-229.

Kender, W.J., U. Hartmond, M. Salyani, J.K. Burns, and J.D. Whitney. 1999. Injurious effects of metsulfuron-methyl when used to stimulate abscission of 'Hamlin' oranges. HortScience 34:904-907.

Kender, W.J., U. Hartmond, R. Yuan, L. Pozo, and A. Grant. 2000. Factors influencing the effectiveness of ethephon as a citrus fruit abscission agent. Proc. Fla. State Hort. Soc. 113:88-92.

LaRossa, R.A. and J.V. Schloss. 1984. The sulfonylurea herbicide sulfometuron is an extremely potent and selective inhibitor of acetolactate synthase in Salmonella typhimurium. J. Biol. Chem. 259:8753-8757.

Li, H., J-J. Shen, Z-L. Zheng, Y. Lin, and Z. Yang. 2001. The Rop GTPase switch controls multiple developmental processes in Arabidopsis. Plant Physiol. 126:670-684.

Ma, L., X. Xu, S. Cui, and D. Sun. 1999. The presence of a heterotrimeric G-protein and its role in signal transduction of extracellular calmodulin in pollen germination and tube growth. Plant Cell 11:1351-1364.

Martin, G.C., R.C. Campbell, and R.M. Carlson. 1980. Effect of calcium in offsetting defoliation induced by ethephon in pecan. J. Amer. Soc. Hort. Sci. 105:34-37.

Martin, G.C., S. Lavee, and G.S. Sibbett. 1981. Chemical loosening agents to assist mechanical harvest of olive. J. Amer. Soc. Hort. Sci. 106:325-330.

Pozo, L.V. and J.K. Burns. 2001. Ethylene action inhibitors reduce Ethrel-induced leaf drop and gummosis in citrus. Proc. Intl. Citric. Soc. (in press).

Sisler, E.C. and M. Serek. 1996. Compounds controlling the ethylene receptor. Bot. Bul. Acad. Sinica. 40:1-7.

Ullah, H., J-G. Chen, S. Wang, and A.M. Jones. 2002. Role of a heterotrimeric G-protein in regulation of Arabidopsis seed germination. Plant Physiol. 129:897-907.

Warner, H.L. and A.C. Leopold. 1969. Ethylene evolution from 2chloroethylphosphonic acid. Plant Physiol. 44:156-158.

Wilcox, M. and J.B. Taylor. 1997. Citrus abscission at very low application rates. Proc. InterAmer. Soc. Trop. Hort. 41:145-151.

Wilson, W.C. 1973. Problems encountered using cycloheximide to produce abscission of oranges. HortScience 8:323-324.

Wilson, W.C., D.S. Kenney, and R.E. Holm. 1977. The Florida Department of Citrus cooperative screening program for citrus. Proc. Intl. Soc. Citricult. 2:692-696.

Yuan, R., U. Hartmond, and W.J. Kender. 2001. Physiological factors affecting response of mature 'Valencia' orange fruit to CMN-Pyrazole. II. Endogenous concentrations of indole-3-acetic acid, abscisic acid, and ethylene. J. Amer. Soc. Hort. Sci. 126:420-426. 